\title{
Social Exclusion/Inclusion in the Context of Hungarian Sport
}

\author{
Gyöngyi Szabó Földesi
}

Faculty of Physical Education and Sport Sciences, Semmelweis University Budapest, Hungary

ABSTRACT

Similar to international trends, this investigation of social exclusion/inclusion from sport was preceded by studying the impact of poverty on sport participation in Hungary. Research was made on inequality of chances and on the disadvantaged position of the lower classes in sport, even in state socialism. Following the transformation of the political regime in 1989-1990, there was a growing interest in exploring unequal social opportunities in sport, not only by marginal social groups, but also by the increasing number of lower middle class people dropping behind. However, Hungarian sport has never been studied in the context of social exclusion/inclusion. The objective of this paper is to approach sport in Hungary from these perspectives. Attempts are made to answer the following questions: in which fields of Hungarian sport can social exclusion be observed? How is social exclusion from sport linked to age, gender, dwelling place, socio-economic status and to the lack of cultural and social capital? How is the concept of social exclusion/inclusion understood by the actors in Hungarian sport? How can sport be used as a means to promote social inclusion for people marginalized by economic, social and cultural barriers? In order to answer the above questions, the following methods were used: analyses of recent research findings on Hungarians' sport participation with a focus on deprivation; indepth interviews with key persons $(\mathrm{N}=15)$ in Hungarian sport with the aim to discover how the concept of social exclusion/inclusion is understood by them; and analyses of documents to explore which measures have been taken by sport policy to tackle social exclusion. The results show that exclusion from sport is widespread in Hungarian society. It is linked in a combined way to poverty, education, ethnicity, age, and settlements. It is established in early childhood and lasts the whole life cycle. Key excluded groups are in hopeless situations due to economic, social and cultural aspects, so they cannot overcome this problem alone. They receive assistance in several other areas, but they are left to their own resources in sport-related issues. Legally they should have access to sport, but they cannot claim their rights. The concept of combating social exclusion is generally not incorporated into the objectives and values of sport clubs and federations; it has not yet been an integral part of sport culture in Hungary. Government documents contain declarations in connection to tackling social exclusion, but very few actions are implemented to promote social inclusion. A major conclusion of the paper is that a serious modification of sport policy does not mainly depend on the lack of financial recourses but on the lack of a strong determination of the Government. The involvement of the Hungarian population in sporting activity and the intention for their inclusion are much lower than it could be under the present economic circumstances. sport culture, sport policy, sport involvement 


\section{Introduction}

In the European Union, the proportion poor relative to the general population, and some of the socio-demographic characteristics of the poor, have been studied since 2001 on the basis of unified indices. Major changes over time have been compared. Although there have been some improvements in a few member states, on the whole the percentage of the have-nots has not decreased. According to recent data 80 million people $-16 \%$ of the EU population - live below the poverty line. In the case of children, the rate is somewhat higher, $19 \%$.

In Hungary $12.7 \%$ of the total population, and $19 \%$ of the children, are hit by income poverty. On the other hand, if we take into consideration the poverty line determined by the National Statistical Office, nearly one-third of the population live below it (Farkas 2010).

These people all over Europe are not merely poor, but are excluded from things in life that most members of society can take for granted. The key excluded groups are children, low-income families, the elderly, the unemployed, the homeless, ethnic minorities and people with disabilities.

The European Union considers it as one of its major tasks to tackle social exclusion and to promote social inclusion. Therefore the European Commission designated 2010 to be the European Year for Combating Poverty and Social Exclusion. The major aim of this action is to raise public awareness about this important issue. The activity of this special year is based on the following key principles:

- "All people have a right to live in dignity and take part in society;

- The public and private sector share responsibility to combat poverty and social exclusion;

- Eradicating poverty for a more cohesive society benefits all;

- Commitment at all levels of society is needed to achieve this goal."

(Combat Poverty Agency

http://www.combatpoverty.ie/news/EY2010.html)

As a consequence of the above designation, international and national programmes were prepared to combat social exclusion and to promote social inclusion. Nowadays it is widely recognized that social exclusion is present in sport as with other areas of society. However, until recently just a few investigations related to this problem were carried out from a sociological perspective. The European Year for Combating Poverty and Social Exclusion gave impulse to research in connection with social exclusion/inclusion in several areas of societies, including sport, throughout Europe; Hungary is not an exception. Actually, this is the first attempt to study Hungarian sport comprehensively in the context of social exclusion/inclusion.

\section{What do social exclusion and inclusion mean?}

Since in sport-related literature the concept of social exclusion and inclusion has been used not for a long time, by way of introduction it seems to be necessary to define their meaning. The terms of poverty and social exclusion have long been treated as synonymous. The idea of social exclusion emerged in France. It was used for the first time by Rene Lenoir (1974), a French Secretary of State for Social Action to government, and it was shortly thereafter adopted in the U.K. Other European and overseas countries followed, and finally the European Union adopted the language at a time when unemployment was rising in the region. Now it is already in everyday EU language.

From the very beginning experts dealing with this theme have agreed that exclusion is a more heterogeneous and more complex concept than poverty. However for a while the French and the Anglo-Saxon approach was dissimilar and could be clearly distinguished. The French concept put more stress on the processes that lead to poverty, shifted the focus from individuals or groups to local communities, and mostly looked for the causes of exclusion in the unsuccessful efforts of communities to integrate people excluded for multiple reasons. The Anglo-Saxon analysis was more static. It placed more emphasis on the significance of the individual's income poverty, their unemployment, and their 
reduced accessibility to goods, services, facilities and to social networks, all linked to their circumstances, habits and poor skill levels.

In recent decades social exclusion terminology shows more similarities than differences in the individual countries. The term exclusion is used by several disciplines including sociology, political sciences, economics, psychology, and education. It takes various relative senses; however, across the above disciplines, it is widely accepted that although a decent income is needed, exclusion comprises several non-economic characteristics, and is closely tied to unequal opportunities. It can be examined along the following major dimensions: economic, societal, political, cultural, temporal, and personal. One of the most largely used definitions is given by the Oxford Dictionary of Politics:

"Social exclusion refers to lack of participation in society and emphasizes the multidimensional, multi-layered, and dynamic nature of the problem. Definitions of the concept emanate from diverse ideological perspectives, but most share the following features:

(1) Lack of participation. Protagonists differ over which aspects of society are important and where responsibility for non-participation resides. Most agree that exclusion is a matter of degree, since individuals may be participating to a greater or lesser extent, and that it is relative to the society in question.

(2) Multi-dimensional. Social exclusion embraces income-poverty but is broader: other kinds of disadvantage which may or may not be connected to low income, such as unemployment and poor self-esteem, fall within its compass.

(3) Dynamic. The advent of dynamic analysis and a demand from policy makers to investigate cause as well as effect has generated an interest in the processes which lead to exclusion and routes back into mainstream society.

(4) Multi-layered. Although it is individuals who suffer exclusion, the causes are recognized as operating at many levels: individual, household, community, and institutional."

(Political Dictionary. The Concise Oxford Dictionary of Politics http://www.answers.com/topic/social-exclusion)

The concept of social exclusion was adopted at the European Union level in the late 1980s, and an inclusionary policy has been promoted since the early 1990s. In 2000, EU member states were called on to take steps to eradicate poverty. The concept of social exclusion was replacing poverty, which is more static. The European Commission's 1992 Communication towards a Europe of solidarity [COM (92) 542] describes social exclusion as the result of

"mechanisms whereby individuals and groups are excluded from taking part in the social exchanges, from the component practices and rights of social integration and of identity. Social exclusion goes beyond participation in working life; it is felt and shown in the fields of housing, education, health and access to services".

(Eurofound, Social Exclusion European Commission definition on social exclusion.

http://www.eurofound.europa.eu/areas/industrialrelations/dictio nary/definitions/SOCIALEXCLUSION.htm)

In the $1990 \mathrm{~s}$, the growing intention to combat poverty, social inequalities and marginalization led to a shift from exclusion to inclusion. Several authors emphasized the twin mechanism of the two notions. They were regarded as a converse of each other, which can be described the best as if they were

"on a continuum on a vertical plane below and above the 'social horizon'; they have a ten-phase modulating ("phase" because they increase and decrease [modulate] with time) 
social structure: race, geographic location, class structure, globalization, social issues, personal habits and appearance, education, religion, economics and politics."

(Wikipedia article "Social Exclusion"

http://www.answers.com/topic/social-exclusion)

Social inclusion is often defined as a social process of incorporation into an exclusive group and it is seen in the first place as an access issue (Donnelly \& Coakley 2002). It is also regarded as an affirmative action taken to change the causes that lead to social exclusion. Politicians started to utilize these terms and social inclusion became a priority in political programmes in a few welfare states. The practitioners also formulated definitions that helped support their arguments, e.g. in the U.K., where an inclusionary policy was introduced relatively early. The following definition, created by the government's social unit, became popular in practice: Social exclusion is

"what can happen when people or areas suffer from a combination of linked problems such as unemployment, poor skills, low income, poor housing, high crime, bad health and family breakdown"

(www.odpm.gov.uk).

\section{Social exclusion/inclusion in sports research literature}

\section{Special meaning of exclusion/inclusion within the world of sport}

The concept of exclusion was originally used in a narrower context in sports research literature. It referred to the exclusion of athletes with certain characteristics (e.g. ethnicity, nationality) from particular positions in sport, and it was discussed in connection with other topics, such as racial and ethnic minorities, discrimination, and social mobility. As early as the mid-1960s, a special phrase, called stacking, was coined by Harry Edwards. Stacking is synonymous with position allocation, which means a positional segregation. It is a form of exclusion within the world of sport since it limits and restricts ethnic minority group athletes' access to central positions in team sports (Edwards 1973).

Particular attention was paid to the case of black athletes. It was emphasized that position allocation is not supported by laws enacted by legislative bodies; it is a form of de facto segregation based on customs and traditions. Several explanations are given for stacking: social, cultural, economic, social psychological, psychological and biological. From a sociological perspective, the stereotyping hypothesis, the attractiveness of position hypothesis, and the outcome control hypothesis seem to be the most relevant. The stereotyping hypothesis assumes that ethnic minority group athletes do not have those physical, psychological and personal characteristics with are needed for occupants of central playing positions. The attractiveness of position hypothesis suggests that minority group athletes stay away from certain positions in team sports that they consider to be unattainable for them. The outcome control hypothesis is connected to managers' and majority group players' prejudices. They exclude minorities from positions of leadership and control, because they suppose that they are not suitable for such tasks, and they cannot properly execute these behaviours (Leonard II 1988).

Another form of exclusion within the sport system examined by sport sociologists is connected to withdrawal from playing. Based on research findings it is concluded that athletes belonging to racial and ethnic minorities are excluded from promotion to sport leadership positions, such as the role of coaches, managers, officials, executives, and owners after their retirement from sport (McPherson et al. 1989).

The term of inclusion is also treated in a specific context within sport, namely, related to discrimination. There might be a counterproductive consequence to the lower-class perception of sport as a vehicle for upward social mobility, since attempts to come out of the ghetto through a professional sports career might discourage them from learning other skills. The mechanism by which involvement in sports distracts people from more realistic avenues to success, especially from education, is called discrimination by social inclusion (Bryant \& McElroy 1997). 


\section{Key literature on social exclusion/inclusion in sport}

Consideration of social exclusion in sport become meaningful just a few years ago, following the spread of the term in both social sciences and in social policy. However the disadvantaged position of the have-nots in sport was examined in sociology early on. Unequal opportunity for involvement in sport has been mostly studied from the perspective of social class, stratification, status, social mobility, social inequalities, and social division. There has been strong scientific evidence that participation in sport (and spectator preferences) can be correlated with socio-economic status and poverty; unemployment and low education contribute to a great extent to the high sedentary rate of the lower social strata (Lüschen 1969, Loy 1972, Gruneau 1975, Bourdieu 1978, Bryant \& McElroy 1997). The topic was studied mainly in the UK and in a few other welfare states where efforts were also made to tackle social exclusion with the help of sport.

Substantial academic literature about the relationship between sport and social exclusion exists approximately for one decade. In 1999 Collins et al. gave a comprehensive overview of literature connected to sport and social exclusion obtained via an international library search on databases, specific Information Centres, as well as via email, phone, and personal requests to scholars in 20 countries relevant from this point of view in Europe, North America and Australia. The authors demonstrated that out of 1713 items there were 333 hits, but only 180 could be used and "eleven studies could be found with anything approaching rigorous evaluations, and some of these did not give specific data for excluded groups or communities" (p. 4).

Since that time the situation has been changed. Not always exclusively or specifically on social exclusion, but several chapters in recently published books touch upon the issue, offering theoretical explanation or empirical findings (Coakley \& Dunning 2002, Sudgen \& Tomilson 2002, Tomilson 2006, Jarvie 2006, Coakley 2007, Houlihan 2008). Special attention was paid to the relationship between social capital and social exclusion from sport (Jarvie 2003, Coalter 2007, Persson 2008), and to the mechanism of social exclusion and inclusion (Elling \& Claringbould 2005).

Since the mid-1990s, when the European Commission put the problem of social exclusion to the agenda with specific emphasis, there has been increasing interest in the implementation of inclusion policies (Roche \& Annesley 1998, Dunning \& Coakley 2002). Policy makers in a few countries, first of all in the UK, incorporated inclusion policies in their national programmes (Social Exclusion Unit 1998, Governments Plans for Sport 2001, Game Plan 2002) that were also based on comprehensive research reports (Collins et al. 1999). Moreover, the exploration of possibilities to tackle social exclusion also came to the spotlight at the community and club levels (Anstett \& Sachs 1995, Roberts 1996, Holden \& Wilde 2004).

Although sport is regarded as a means to combat social exclusion, the related literature is very critical of the role of sport in government policy. Researchers attempt rather at discovering the ways in which sport may contribute to social exclusion. A key work was published by Collins, with Kay (2003). This book deals exclusively with sport and social exclusion and explores the complexity of the issue. Based on a wide theoretical background the book presents the manifestation of social inclusion in connection with different topics, e.g. poverty, gender, age, education, dwelling place, disability, youth delinquency, and policy implementation. The presentation of these themes is followed by long list of publications related directly or indirectly to the individual issues.

Similar to international trends, the investigation of social exclusion/inclusion from sport was also preceded by studies on the impact of poverty on sport participation in Hungary. Research was done on the inequality of opportunity and on the disadvantaged position held by lower classes in sport, even under state-sponsored socialism, but a few decades later than western democracies. Under statesponsored socialism, poverty and deprivation were taboo subjects in all areas of society, and sport as a social subsystem was no exception. However this was not the major reason that the study of the disadvantaged position of the lower class in sport was neglected. In the emerging Hungarian sport sociology of the 1960s and 1970s, research focused partly on scientific identification of the discipline, 
and partly on problems offered by everyday sports life. By the 1980s, when sport sociology was beyond its infancy, research findings related to the unequal access to different fields of sport by different socio-economic groups (Földesi 1984, Galdi 1986, Laki \&Makszin 1984) were not welcomed, but were tolerated well enough; or, because of the disinterest of decision makers in sport, they were instead totally neglected.

Following the transformation of the political regime in 1989-1990 there was growing interest in unequal social opportunities for sport not only by marginal social groups but also by the increasing number of low-middle class people dropping behind (Galdi 2002, 2004, Gál 2003, 2008, Földesi 1999, 2009). Nevertheless in Hungarian sports research literature, the term of social exclusion was mentioned recently related to some other topics, such as the sporting opportunities of the Roma population in Hungary (Földesi et al. 2010).

\section{Objectives}

The aim of this paper is to approach sport in Hungary from the perspective of social exclusion/inclusion. Attempts are made to find answer to the following questions:

- In which fields of Hungarian sport can social exclusion be observed?

- How is social exclusion from sport linked to age, gender, dwelling place, socio-economic status, and ethnicity?

- How is the concept of social exclusion/inclusion understood by the actors in Hungarian sport?

- How is sport used as a means to promote social inclusion for people marginalized by economic, social and cultural barriers?

\section{Methods}

In order to give answers to the above questions the following methods were used:

- analysis of recent research findings on Hungarians' sport participation with focus on the involvement of disadvantageous groups,

- in-depth interviews with key persons in Hungarian sport (sport leaders, sport managers, physical education teachers) to discover how the concept of social exclusion/inclusion is understood in Hungarian sport $(\mathrm{N}=15)$,

- analysis of documents to explore which measures are taken by sport policy to tackle social exclusion.

\section{Hungarian sport and social exclusion}

\section{In which fields of Hungarian sport can social exclusion be observed?}

Non-involvement in sport is not necessarily the result of social exclusion, since even privileged individuals can avoid playing sport for various reasons based on autonomous decisions. However studies on rates of participation by different socio-economic and demographic groups in the various fields of sport might give insight into the position of disadvantaged people in this specific area of social life, and help reveal some mainstream tendencies. The question whether there are any social or demographic groups at particular risk of social exclusion, and which fields of sport they are excluded from, could be answered after a thorough analysis of statistical data and research findings. Based on the latter it can be rightly stated that, though to a different extent, social exclusion can be observed in all areas of Hungarian sport that is in school sport, university sport, leisure sport, sport for people with disability, and elite sport.

In principle children cannot be excluded from school sport, all of them can participate in different fields and at different levels depending on their skills. In reality in Hungary - according to the statement of a state secretary responsible for sport affairs not long ago - the majority of the roughly 1,5 
million pupils practice sport exclusively in the framework of physical education classes. Compared to international data, they do sport much less frequently than children of the same age in the EU, therefore their endurance shows a negative tendency (Török 2009). Physical education classes are compulsory, but generally speaking their standard has been deteriorating for several years and there are huge differences between schools in this respect. In addition, many children from disadvantaged families, especially a large proportion of Roma children do not even finish elementary school; many of them do not attend upper classes, where physical education is taught by PE teachers who could notice their talent and could arouse professionally their interest in sports.

Moreover, pupils playing sport in sport clubs have priority in school sport. For the most part they are involved in the national student championships called Student Olympics, organized by the Hungarian School Sport Federation in 12 sports, in 6 age groups. Students compete in the colour of their school in the other fifty championships that are organized in co-operation with national sports federations. It means that access to sport in school for children who are members in sport clubs is doubled, while for other students, the opportunities for exercising at educational establishments and competing in the colours of their school are limited.

University students are in a better situation concerning sport participation, as social exclusion hardly occurs there. It is true that their chances for practicing sport at local level depend on the conditions and management of sport at their universities. At the same time they have more opportunities for competing at different levels regionally and centrally (Hédi 2009). It is quite probable that those university students who do not play sport or do not exercise are not excluded but they make independent decisions. Notwithstanding, it has to be underlined that they constitute a special social group, the members of which are generally in a better position socially, culturally, and partly economically than common young people in the same age category.

Recreational sport and exercise (mass sport, leisure sport) was never a field for every Hungarian citizen. Not even in state socialism, when equality was also declared to be a core value in sport. Depending on the standard of living, two-thirds or at least more than half of the population could not afford it at all (Galdi 1986, Földesi et al. 1991).

The situation did not become better after the 1989-1990 political and economic transformation. On the contrary, parallel with the increasing social distances and the growing number of the poor in the Hungarian society, more and more people had less and less opportunity to participate in - or had no access to - sport at all (Gál 2008, Földesi 2009). According to the data of the Special Eurobarometer (72.2) 334 on Sport and Physical Activity collected in 2009, Hungarians exercise regularly (at least 5 times a week) much less than most other nations in the European Union; they are at the far end of the scale with $5 \%$, while at the top of the scale one can find Ireland with $23 \%$ and Sweden with $22 \%$. Complementing the ratio of people playing sport regularly with those doing it with some regularity (3 to 4 or 1 to 2 times a week) Hungary is the fourth country from the bottom with $23 \%$. At the other end of the scale Sweden and Finland emerge as having the most people who play sport regularly or with some regularity $(72-72 \%)$. When it comes to never playing sport or doing it less than once a month the results are even more exasperating; Hungary is among the EU countries with the lowest level of participation, that is, the rate of non-participation is the highest (71\%) together with Bulgaria $(82 \%)$ and Greece (79\%).

In the above Special Eurobarometer, there are telltale signs suggesting that the Hungarians' non-participation might not always be the person's autonomous decision but the lack of access. Hungary is among the EU countries where the fewest citizens exercise at fitness centres (2\%) and in sport clubs (3\%). Fitness centres are used the most in Sweden (31\%), and sport clubs are the most popular in the Netherlands (25\%). In Hungary, in both cases, the cost of exercising in these contexts would be too high compared to the average incomes; besides, in several settlements neither fitness centres nor sport clubs are available (http://ec.europa.eu/public_opinion/archives/ebs/ebs_334 _en.pdf). 
It can be regarded as another telltale sign that one-fifth of Hungarians say that illness or disability prevent them from exercising. The fewest people identified this factor are in Italy (3\%) and in Ireland (6\%). Although the reasons for not exercising are more complex, no doubt that this proportion is very high in Hungary; following the United Kingdom (22\%) it is the second-highest in the EU $(20 \%)$. Taking into consideration that socially excluded people can be characterized by poor health, the emergence of these factors can render many Hungarians' exclusion from practicing sport probable.

Sport for the disabled is a controversial area from the standpoint of social exclusion in Hungary. People with special needs were long neglected in sport as a matter of course. Their exclusion was regarded as evident. This situation considerably changed in a positive direction after the 1989-1990 political transformation. It was closely related to the changing position of the disabled in larger society, and it was almost the only really positive alteration in sport. However, the development of the individual fields of disability sport occurred unevenly. High-level competitive sport for people with various disabilities has been supported to a much greater extent than their leisure sport. In spite of new favourable legislation, the majority of the disabled are in fact still excluded from leisure sport, exercise, and physical recreation. Besides, the huge shortage in sporting facilities designed specifically for them often prevent not only recreational/leisure disabled athletes from participation but disabled elite competitors as well (Wisinger 1999).

Since sporting successes in the international arena always had outstanding political functions in Hungary, logically you would expect that not a single social group had been excluded from elite sport. The history of Hungarian top sport shows controversial tendencies in this respect. At the start of modern sport the majority of top athletes belonged to upper-middle or upper classes, and members of elite sports clubs had similar socio-economic background in the first part of the $20^{\text {th }}$ century. After the communist takeover (1945-1948) sport, high-level competitive sport especially became one of the most open sectors in Hungarian society. The youth's participation in competitive sport was supported regardless of gender, dwelling place, education, and social origin because winning at the Olympic Games and at World and European championships had more important roles in internal and foreign affairs than at any time before that political regime. Top sport became less open for young athletes with working class backgrounds in the late 1960s (Földesi 1984), and inequality increased continuously during the 1980s and 1990s (Földesi 1999). Recent research results suggest that the initial opportunities for becoming a top athlete are not really equal. Most children with socially disadvantaged status are excluded even from the Hungarian government-sponsored national sports talent care programmes (Velenczei et al. 2008).

\section{How is social exclusion from sport linked to age, gender, dwelling place, socio-economic status, and to ethnicity?}

Based on recent research data it can be rightly stated that in today's Hungary, exclusion from sport is strongly linked to social and demographic factors (Gál 2008, Velenczei et al. 2008).

The highest proportion of the excluded people in all regions, with both gender and in all ages, belong to the marginalized Roma population. Ethnicity is closely connected to social exclusion from sport. It should be added that Roma people are excluded not only individually, but also at household, community and institutional levels for multiple reasons: a great majority of them are unemployed, they have poor skills, low income, low education, poor housing, and bad health. Their exclusion starts in childhood and continues in the whole life cycle.

In spite of compulsory education a great number of Roma children of school age drop out at very young ages, they are hardly socialized into sport, and their exclusion from the sport system is regarded as natural. They are not only excluded from recreational leisure sport, but almost from all areas of sport as well. Of course, they are equal de jure; however the competitive sport system hardly accepts them. Prejudices against the Roma ethnic group are present in sport as in larger society. The 
idea of inviting Roma youth and helping their involvement is far from most sports clubs except for clubs or sport sections specializing in boxing. In 2010 more than half of the young boxers participating in the state-financed talent care programme consist of Roma adolescents; this is the only sport where they are welcomed and where a relatively large number of them can reach the top. They have very little chance, if any, to become top athletes in other sports.

The disabled Roma population has been in multiple-jeopardy, a state in which their disability, plus the additional impact of their ethnicity, and in all probability their low socio-economic status prevent them from involvement in and through sport. Their exclusion is even more evident in sport than in most other fields of society.

The non-Roma Hungarian population with low socio-economic status, the proportion of which has been seriously growing for two decades, also has little chance to exercise and play sport. The lack of economic and cultural capital is the more decisive reason for non-participation (Gál 2008). Comparing recent findings with data from research carried out two decades ago, it appears that social distances have been increasing in sport. "The differences in the rates of sporting activity due to education, occupation, and income have become greater" (Földesi 2010, p 84.). At the same time the impact of age, gender, and partly dwelling place lessened somewhat in the last twenty years.

It has to be emphasized that Hungarians' non-participation cannot be always directly connected to social exclusion. In many cases it is rather rooted in the people's negative attitudes. In a recent study when explaining their absence from sport the dislike of sporting activity was listed in the second place among the main reasons (Gál 2008). According to the findings of the Special Eurobarometer (72.2) 334 on Sport and Physical Activity, 12\% of the Hungarian respondents declared that they had an aversion to competitive activity, and this prevented them from exercising.

(http://ec.europa.eu/public_opinion/archives/ebs/ebs_334_en.pdf). On the other hand, it is quite likely that the present negative attitudes originate in the lack of positive experiences, especially in the early phase of their sport socialization, which might be the result of social exclusion from sport in their childhood. Although the exact rate of the latter can only be estimated, in all probability in today's Hungary the have-nots are excluded from sport involvement even more than they were in state socialism.

\section{How is the concept of social exclusion/inclusion understood by actors in Hungarian sport?}

Polarization of Hungarian society and the continuous impoverishment of the low-middle- and lower-class population cause anxiety all over the country. People express their concern, realizing that more and more of them can rely mostly on informal and second-hand channels to acquire goods, and more and more of them are excluded from mainstream cultural consumption. Actors in sport are no exceptions in this respect. However, the preponderant majority of them are of the opinion that exclusion from sport is a relevant problem only from one aspect, namely: elite sport can recruit new athletes from a narrower base. Otherwise this issue can be neglected in its entirety.

It has been recognized in sports federations and sports clubs that they surely lose many potentially talented young persons who could even be world champions, because they lack the necessary economic and cultural capital to join them. Nevertheless, only few sport organizations make serious attempts at promoting poor children's inclusion in their activity. The Hungarian Boxing Federation can serve as a good example. The management of that federation looked for and found sponsors with the support of which a large number of children with disadvantageous socio-economic background could be invited to get acquainted with boxing in three towns across the country, out of which two are in the centre of disadvantaged regions.

Social objectives are not incorporated into the existing aims and values of most sports federations and clubs, consequently not into their actions. They blame "the state" for not supporting the recruitment of a fresh supply for elite sport in a more effective way and they expect the 
government to solve this problem. The other side of the coin is that, with a few exceptions, sport clubs are not in the position to recruit a lot of children, to select the best ones, and train them from the start as the elite athletes' successors. They have neither the financial means nor the plans for long term investment; they prefer to buy ready-made athletes. It might seem paradoxical that a new tendency can be observed. Namely, instead of inviting poor children, several sport clubs regard well-to-do children's early involvement in sport as a means for earning money; they offer courses in various sports to beginners on a self-financing base.

The same attitudes and behaviours can be observed with the actors in Hungarian sport related to potential participants in all ages. In theory the heterogeneous Hungarian club sector could be suitable to contribute to combating exclusion. In practice the majority of clubs of varying sizes and varying levels of resources lack the culture to deal with such a social issue. The want of solidarity is one of the main characteristics in today's Hungarian sport.

In spite of the fact that the majority of leisure athletes practice outside organizational framework, the number of sports clubs outside the competition system has been growing in the last decades. Nevertheless, generally speaking they are small and rather powerless. They focus on their immediate objectives and have very limited financial conditions. Many of them registered because they are in need for external funding and wanted public support for their operation.

The major sports clubs connected to the competition system would have better chances and could be expected to be committed more to struggling for social aims. However they have different financial and cultural backgrounds and function in a different way than the Western-type sports clubs. Their number dropped radically and their legal status has changed in the last two decades, but they still follow the old traditions rooted in the so-called socialist sport model. They are mostly interested in high-level competitive sport and most of their members, including children, hold a competition licence. They do not consider as their task providing non-competitive athletes with sporting opportunity, or promoting the physical fitness and health awareness of the population through sports activities. Although sport clubs are non-governmental institutions, a great number of them function as if they were government bodies. They prefer to work with talented athletes and they push them to win as many medals in the international arena as possible. This situation is not due to managers' and coaches' personal mistake, but to the faulty sport policy. The major sport clubs are expected to produce successful athletes and they receive financial support from public money according to their athletes' sports performances. Under such circumstances it is out of question that they could care about people excluded from sport and promote their social inclusion.

\section{How is sport used as a means to promote social inclusion for people marginalized by economic, social and cultural barriers?}

Sports clubs are involved in their local community to different degrees but regardless of the varying level of their involvement, there is little co-operation between communities and the clubs concerning social exclusion/inclusion. Local governments make enormous efforts to cope with social exclusion of a great number of people living in their settlements. The lower section of the middle class is already hit by poverty; the lower strata of the large working class and the similarly large low class can be classified below the poverty line.

The size of disadvantaged social groups has continuously been growing in most towns and villages, and a considerable percentage of the population is living in disadvantaged regions where the core of exclusion is poverty, but it is combined with other factors: the poor are generally semiilliterate, unemployed, and have poor skills, poor housing, bad health and belong to ethnic minorities. The latter constitute the key excluded groups: children and elderly, low-income families, the disabled, and the homeless. 
Under these circumstances, local governments must not leave socially excluded people to their own resources in sport (Földesi 2009). Despite this rightful claim it is partly understandable that inclusion into sport and into community through sport is not a high priority for local governments. Although they are responsible legally for supporting sports of population living in their territory and to ensure equal access to all local public services, most of them are not in a financial position to act accordingly. They have anti-poverty programmes, but this is centred on helping marginalized social groups to survive. Since their budget was cut several times in the last decade, and most of them struggle with budget deficits, they consider the disadvantaged groups' access to culture and sport as an issue of secondary importance. Consequently there is an enormous shortage of accessible local sports services, especially in rural communities, but also in the disadvantaged suburbs of urban settlements. The Act on Local Government identifies their responsibility for supplying their population with sports services as non-mandatory and targeted state normative subsidies are not allocated to them for sport, so they think to have all reasons to ignore it.

The other side of the coin is that the promotion of sport for all inhabitants is not an integral part of local government culture, especially as far as social policy is concerned. According to their tradition, sport can be used as a tool to develop local patriotism via sporting successes in the first place, the fact that sport could promote social inclusion and it could essentially contribute to the improvement of the quality of life is often neglected. This statement can be demonstrated by several facts. In a great number of towns and villages there is a huge shortage of outdoor and indoor sports facilities, swimming pools, ice rinks, and school gymnasiums. Local governments partly inherited, partly produced these conditions. They avoid supporting the construction of sporting facilities since the operating costs would be high, and their anxiety in not groundless. However most of them regard this problem exclusively from economic aspects, that is, taking into consideration what they would lose financially in short term and not what they would win socially, culturally, morally and even economically, in the longer term. It has to be added that settlements in disadvantaged regions cannot resolve the problems concerning lacking and existing sports facilities at their own expense; they need external help from the central government and/or from the business sector.

In the face of want for sporting facilities and with a strong intention to use sport as a means to reduce social exclusion, the excluded groups have little chance to practice sport. Communitysponsored opportunities for regular sporting activities are lacking or strictly limited. There are occasional events organized by non-government sporting bodies within the framework of various campaigns and financed mainly by public money, but these are not enough to serve the social inclusion of marginalized groups.

The lack of social exclusion policy related to sport affects the children from poor families the most. Children facing social exclusion hardly have any chance to practice sport regularly. After-school sport programmes are not offered to them on a regular basis in most schools, and they cannot afford to pay for sports courses or fitness clubs, if there are such opportunities in their settlement at all. Thus they miss not only the benefit of sport participation but also the opportunity to enjoy social and moral inclusion through sport. Surprisingly, beside financial and administrative problems, physical education teachers are blamed for the children's insufficient involvement in sport even in official documents (Sport XXI Nemzeti Sportstratégia 2007). According to the findings of our inquiry the situation is often just the opposite. There are quite a few enthusiastic P.E. teachers who generate active sport life in their school for pupils with disadvantageous background, in spite of the well-known fact that they are underpaid. Similarly, actions with the aims for involving delinquent youth or youth from broken families into sport were initiated by individuals. In some cases their initiations had happy ending, that is, sport authorities took them up (e.g. midnight table tennis, homeless football). No doubt, it should be just the other way around.

In the mirror of political documents, such an exasperating picture could not be expected. According to the National Sport Strategy in force, to ensure equal opportunities, to reduce geographical, financial and social inequalities, to promote integration and to strengthen national as 
well and community identity are strategic priorities of sports policy. It is declared that actions offering equal opportunities, shaping and satisfying sporting needs, and diminishing regional differences should be supported with special care. Besides, the development of leisure sport, school and student sport are included into the main areas and aims of sport policy, and it is recommended that inclusion into these fields should be assisted by benefits (Sport XXI Nemzeti Sportstratégia 2007). In the last few years, announcements for financial support by the highest sport authorities generally gave opportunity to submit applications connected to sport for disadvantaged groups and for population with special needs. A handbook and other guidelines were published by the sport secretariat offering assistance in how to submit applications. The action plans related to the realization of the objectives worded in the National Sport Strategy always include the necessity for fostering the marginalized groups' access to sport. The aforementioned facts constitute the sunny side of the situation the shadow side of which is radically larger. The reality is that the action plans have never been realized in this context. These parts of the plans were always built on non-existing additional funds, so their unfeasibility was obvious at the moment of the planning (Földesi 2009). If additional resources were allocated to the central sport budget, it was given either to football or to high-level sport. For instance, in 2009 such additional funds were even officially called Beijing plus. The system of application for financial support in sport has been functioning in a dysfunctional way in many respects; it is unsuitable for contributing to combat exclusion and promoting inclusion.

It has to be admitted that there were a few well-intentioned actions on behalf of the highest sport authorities. For instance, just in the recent past, the preparation for, and participation in, international matches were financed for the Hungarian Roma football teams, and some junior Roma football teams; special summer camps for disadvantaged youth, as well as the broadening the sporting opportunities for disabled and marginalized young people living in community homes, were supported; and a few programmes were launched by the State Secretariat responsible for sport (Tornai 2007, Török 2009). However these occasional shots do not replace a well-established concept and continuous and consequent actions. Moreover it is a misunderstanding to believe that the government body responsible for sport should deliver services. It should rather invest in sport on a more systematically planned basis and co-ordinate between sectors, such as education, health care and sport. The highest sport authority should contribute at a much higher degree to raise awareness about the social significance of sport, and to share responsibility for tackling social exclusion and foster social inclusion.

The great importance of volunteering in sport is also emphasized in documents, but volunteer activity is not always properly evaluated by top managerial personnel. Quite amazingly a good many sport bureaucrats of some non-governmental sporting bodies do not hold volunteer sports leaders in high esteem. These sport bureaucrats consider the survival of their job as the first priority and reject the critical remarks of volunteers who, due to their independence, might take opposite views on the rank of organizational objectives. Coaches, sport instructors, club managers appreciate greatly the volunteers' work. They experienced that the recent decline in volunteering has already caused heavy losses to Hungarian sport. Since in the same period the number of full-time employees also decreased, and their rate is lower than in most countries in the European Union, there are not enough people in sport associations and clubs who could focus their attention to the involvement of marginalized groups in sport. The idea to invite people marginalized by economic, social and cultural barriers to volunteer, thereby fostering their participations in decisions that concern their lives, was not spread, not even raised in sporting bodies.

\section{Conclusions}

In Hungarian sport it had been recognized later than in most countries in the European Union that social exclusion is present in sport as well as in other areas of society, and sport also can be a means of combating social exclusion and advancing social inclusion. Based on this comprehensive 
overview it can be stated that exclusion from sport is widespread in Hungarian society. It is linked to poverty, education, ethnicity, age, and settlements in a combined way. It is established in early childhood and lasts in the whole life cycle. The key excluded groups are in hopeless situation from economic, social and cultural aspects, so they cannot overcome this problem alone. They receive assistance in several other areas, but they are left to their own resources in sport related issues. Legally they should have access to sport but they cannot claim their rights.

Generally speaking, social exclusion/inclusion is not a relevant topic in Hungarian sport. It is already present in political documents but sport policy proves to be incapable of taking efficient actions. Hungarian sport policy is "one-sided'; it focuses on promoting Hungarian athletes' success on international level and does not pay serious attention to social issues. The latter has not been yet an integral part of sport culture in Hungary. On the other hand utilizing sport for combating social exclusion and promoting social inclusion is neglected in social policy, since the social significance of sport is largely underestimated. This is also manifested in the fact that sport policy cannot rely on the true partnership of educational policy. In the last two decades governments did not place special emphasis on physical education (PE) and school sport. There were a few well-intentioned attempts at changing this situation, but until recently PE has remained as one of many subjects. The construction of related educational facilities and playing fields had no true priority in communities. P.E. teachers are not well paid and are not motivated for developing extracurricular sports programs. The particular social benefits of sport for school children are not given true importance, as if it were not evident that children who are excluded from sport have much less chance to do sport in their future life. Investment in school sport is not considerably higher than it is the low grassroots investment in sport for all. The co-operation between different sectors is insufficient; sport, education, social affairs, and health care do not have well-harmonized policies. In spite of frequent rhetoric for joint-up thinking and operating, the co-ordination mechanism does not work well. As a result, communities, schools, associations, clubs initiating and extending sporting opportunities to disadvantaged people are not supported in a harmonized way and they cannot rely on a continuous support.

Since the year of 2010 is designated to be the European Year for Combating Poverty and Social Exclusion, similar to other member countries, a national program for tackling poverty and social exclusion was prepared in Hungary. The national programme includes sport, briefly suggesting that the topic of poverty should be presented and stressed at sport-related events. However, this special year might offer the opportunity for analyzing the actions implemented by the European Union and to follow some of them. Thereby it could induce changes in Hungarian sport policy concerning social exclusion/inclusion. As a first step, with the aim of demonstrating Hungary's good will, competitions for special support connected to the theme were already announced for sport organizations. On the other hand, it is feared that, referring to the current financial crisis, only a few programmes will be backed financially, and true changes will be postponed once again. In today's Hungarian sport, one can simultaneously notice the shortage of money and the waste of money. The major conclusion of this paper is that the actual lack of money is often just a pretext for explaining the contradictory character of current sport policy. Several elements of an even serious modification of sport policy do not depend mainly on economic background but a strong determination of the government. Scientific evidence justifies the assumption that the Hungarian population's involvement in sporting activity, and the intention for their inclusion, are much lower than it could be under the present economic circumstances. In the following a few modest recommendations are made for promoting alterations:

- priorities of state responsibility for sport should be modified in practice. state responsibility for every citizen's participation in sport should be increased,

- state determination for tackling social exclusion from sport should be boosted,

- central government should better co-ordinate between sport, education, health care, and social policy,

- organisational reform should be introduced and then structural changes should be stopped for long, 
- state relationship with the voluntary and private sectors should be put on a basis of mutual partnership; the public and the private sectors should share responsibility for combating social exclusion from sport,

- non-governmental sport organizations should not build their activity mainly on public money,

- the management system should be improved and the professional skills of sport management should be developed,

- a higher proportion of funds should be spent on grassroots sport and less on bureaucracy,

- the struggle for receiving higher share from the central state budget for sport can be continued but the existing budget allocated for sport should be used more rationally and economically.

It can be rightly supposed that if at least half of these proposals were approved, fewer people would be excluded from and more people would have better access to sport.

In his famous book on social exclusion policy and sport, Mike F. Collins (2003) emphasized that his work was written with the aim to alert and to warn researchers and policy makers and to persuade them "to be committed to policies and practices to increase inclusion despite the whim of politics" (p. 2). The author of the present paper thinks that the aims of her paper can be expressed the best with these words. The upsetting facts presented above are suitable, in all probability, for alerting and warning both researchers and policy makers in Hungarian sport. Whether the argumentation presented here is strong enough or not to increase their commitment and responsibilities, and to persuade them to do everything possible they can by virtue of their power to combat social exclusion from and to promote social inclusion into and through sport, remains to be seen in the future.

\section{REFERENCES}

Anstett, M., Sachs, B. (1995). Sports, Jeunesse et logiques d'insertion. Paris: Ministere de la Jeunesse et des sports.

Bourdieu, P. (1978). Sport and Social Class. Social Science Information. 17, 6, 819-840.

Bryant, J. E., McElroy, M. (1997). Sociological Dynamic of Sport and Exercise. Englewood, Colorado: Morton Publishing Company.

Coalter, F (2007). Sport Clubs, Social Capital and Social Regeneration: Ill-Defined Interventions With Hard To Follow Outcomes? Sport in Society, 10, 4, 537-559.

Coakley, J (2007) Sport in Society: Issues and Controversies. New York: McGraw - Hill.

Coakley, J., Dunning, E. (Eds) (2002). Handbook of Sport Studies. London: Sage Publications.

Collins, F. M., Kay, T. (2003) Sport and Social Exclusion. London: Routledge.

Collins, M., Henry, I. P., Houlihan, B., Buller, J. (1999). Research Report: Sport and Social Exclusion. Loughborough: Loughborough University.

Donelly, P., Coakley, J. (2002). The Role of Recreation in Promoting Social Inclusion. Working paper series. Toronto: Laidlaw Foundation.

Elling, A., Claringbould, I (2005). Mechanisms of Inclusion and Exclusion in the Dutch Landscape: Who Can and Wants to Belong? Sociology of Sport Journal, 22, 4.

Edwards, H. (1973). Sociology of Sport. Homewood: The Dorsey Press.

Farkas, Z. (2010). A Magyar Szegénységellenes Hálózat jelentése a szegénységben vagy annak közelében élö gyerekes családok helyzetéröl. Budapest: Magyar Szegénységellenes Hálózat Alapítvány.

Földesi, S. G. (1984). Magyar olimpikonok önmagukról és a sportról. Budapest: Közgazdaság és Jogi Könyvkiadó.

Földesi, S. G. (1999). Félamatőrök, félprofik. Magyar olimpikonok (1980-1996). Budapest: MOB.

Földesi, S. G. (2009). Szabadidősport - életmód - sportpolitika. Hazai és nemzetközi tendenciák. In N. Bendiner (szerk.) Útban a sportoló nemzet felé??? Budapest: NSZSZ.

Földesi, S. G (2010). Hungary. In M. Nicholson, R. Hoye, B. Houlihan (Eds.), Participation in Sport. International Policy Perspectives. London and New York: Routledge.

Földesi, S. G., Gál, A., Dóczi, T. (2010). Sportszociológia. Budapest: TF. 
Földesi, S. G, Földesiné, Sz. Gy., Louveau, C., Metoudi, M. (1991) A sportolásra fordított idő Franciaországban és Magyarországon. A Testnevelési Egyetem közleményei, 1. melléklet. In C. Louveau, M. Metoudi, A sportolásra fordított idő Franciaországban és Magyarországon. A Testnevelési Egyetem közleményei (pp. 1-111).

Gál, A. (2008). A magyar lakosság egészségtudatossága és szabadidő-sportolási szokásai. In S. G. Földesi, T. Dóczi, A. Gál (szerk.), Társadalmi riport a sportról (pp. 9-40). Budapest: ÖM-MSTT.

Gál, A. (2003). Nők formában. In Sz. Gy. Földesiné, A. Gál (szerk.), Sport és társadalom (pp. 145-154). Budapest: MSTT.

Galdi, G. (1986). A szabadidösport iránt érdeklödés vizsgálata különbözö tárasadalmi csoportokban egy szabadidö klub müködése kapcsán. Testnevelésdoktori értekezés. Budapest: Testnevelési Főiskola.

Galdi, G. (2002). Fizikai aktivitás Magyarországon az ezredfordulón. Magyar Sporttudományi Szemle, 3-4, 1618.

Galdi, G. (2004). Szabadidő-struktúra és fizikai reakció Magyarországon 1968-2000 között életmód-időmérleg vizsgálatok tükrében. PhD-értekezés. Budapest: Semmelweis Egyetem.

Gruneau, R. (1975). Sport, Social Differentiation and Social Inequality. In D. Ball, J. W. Loy (Eds), Sport and Social Order. Addison Wesley, Reading: Ma.

Hedi, C. (2009). A Magyar Egyetemi-Főiskolai Sportszövetség (MEFS) hozzájárulása a főiskolásokegyetemisták szabadidős sporttevékenységéhez. . In N. Bendiner (szerk.), Útban a sportoló nemzet felé??? (pp. 79-84). Budapest: NSZSZ.

Holden, P. R., Wilde, N. (2004). Defense or Attack? Can Soccer Club Tackle social Exclusion? ISTR Sixth International Conference. Toronto, Canada, July 11-14. http://www.istr.org/conferences/toronto/workingpapers/ holden.philip.pdf.

Houlihan, B. (2008). Sport in Society: A Student Introduction. London: Sage

Jarvie, G. (2003). Communitarianism, Sport and Social Capital: Neighbourly Insights into Scottish Sport. International Review for the Sociology of Sport, vol. 38, 139-153.

Jarvie, G. (2006). Sport, Culture and Society. London: Routledge.

Laki, L.-Makszin, I.(1984). Életkörülmények-Életmód-Életszínvonal. Sporttudomány, 4, 17-21.

Laki, L., Lakatos, M., Újvári, J. (1990). A magyar népesség testedzési és sportolási szokásai. A Magyar Testnevelési Egyetem közleményei, 2, 11-28.

Leonard II, W. M. (1988). A Sociological Perspective of Sport. New York: Macmillan Publishing Company.

Lenoir, R. (1974). Les exlus: Un français sur dix. Paris: Le Seuil (http://www.yasni.de/person/lenoir/rene/renelenoir.htm [pdf]).

Loy, J. W. (1972). Social Origin and Occupational Mobility of Selected American Athletes. International Review of Sport Sociology, 7, 5-23.

Lüschen, G. (1969). Social stratification and Social Mobility of Young Sportsmen. In J. W. Loy, G. Kenyon, (Eds.), Sport, Culture and Society (pp. 258-276). New York: Macmillan.

McPherson, B. D., Curtis, J. E., Loy, J. W. (1989). The Social Significance of Sport. Champaign: Human Kinetics Publisher.

Persson, T. H. (2008). Social Capital and Social Responsibility in Denmark: More than Gaining Public Trust. International Review for the Sociology of Sport, vol. 43, 35-51.

Roberts, K. (1996). Young people, schools, sport, and government policies. Sport Education \& Society, 1, 47-57.

Roche, M. \& Annesley, C. (1998). Comparative social inclusion policy in Europe: Report 1 Contexts. Sheffield: Sheffield University.

Social Exclusion Unit (1998). Bringing Britain together: a national strategy for neighbourhood renewal Cm 4045. London: Stationary Office.

Sugden, J., Tomlinson, A. (2002). Theorizing Sport, Class and Status. In J. Coakley, E. Dunning (Eds.), Handbook of Sport Studies. London: Sage Publications.

Tomlinson, A. (2006). The Sport Studies Reader. London: Routledge.

Tornai, I. (2007). Gyermekszámlálás Javaslatok a gyermekszegénységet mérő, komplex indikátorrendszerre. Budapest: DEMOS Magyarország Alapítvány.

Török, O. (2009). Tájékoztató a lakosság mozgásgazdag életmódjával kapcsolatos állami szerepvállalásáról 2009-ben. In N. Bendiner (szerk.), Útban a sportoló nemzet felé??? (pp. 11-16). Budapest: NSZSZ.

Velenczei, A., Kovács, Á., Szabó, T., Szabó, A. (2008). Társadalmi változások a magyarországi sportutánpótlásnevelésben egy sportegyesület tükrében. Magyar Sporttudományi Szemle, 4, 25-30. 
Wolańska, T., Salita, J., Jung, R., Mikołajczyk, Z., Pastwa, M., Żyśko, J. (2002). Poland. Sport for All as Physical Culture and Social Value. In L. P. DaCosta \& A. Miragaya (Eds.), Worldwide Experiences and Trends in Sport for All. Aachen: Meyer und Meyer Sport.

Wisinger, J. (2009). A sportirányítás és a fogyatékkal élők szabadidősportja. In Bendiner N. (szerk.) Útban a sportoló nemzet felé??? (pp. 61-67). Budapest: NSZSZ.

Internet sources:

Combat Poverty Agency http://www.combatpoverty.ie/news/EY2010.html

Eurofound, Social Exclusion European Commission definition on social exclusion. http://www.eurofound. europa.eu/areas/industrialrelations/dictionary/definitions/SOCIALEXCLUSION.htm.

Political Dictionary. The Concise Oxford Dictionary of Politics. Copyright (C) 1996, 2003 byOxford University Press. http://www.answers.com/topic/social-exclusion.

Special Eurobarometer (72.2) 334 on Sport and Physical Activityhttp://ec.europa.eu/public opinion/archives/ebs/ebs_334_en.pdf.

Sport XXI Nemzeti Stratégia 2007-2020 (2007). Budapest: ÖTM, Sport. Szakállamtitkárság. www.sporttudomany.hu/dokumentumok/Sportstrategia.pdf.

Wikipedia article "Social exclusion http://www.answers.com/topic/social-exclusion http://209.85.135.132 /search?q=cache:GwbAjRVAmScJ:www.combatpoverty.ie/news/EY2010.html+2010+combat+poverty\&cd=1\& $\mathrm{hl}=$ hu\&ct $=$ clnk\&gl=hu\&client=firefox-.

UK Government's Social Unit www.odpm.gov.uk.

AUTHOR'S ADDRESS: $\quad$ Gyöngyi Szabó Földesi

Semmelweis University

Alkotas utca 44

1123 Budapest

Email: foldesi@hupe.hu 